\title{
Letter \\ Renal failure in the intensive care unit: acute kidney injury compared to end-stage renal failure
}

\author{
Marlies Ostermann ${ }^{1}$ and René Chang ${ }^{2}$, for the Riyadh ICU Program Users Group
}

'Guy's \& St Thomas' Hospital, Departments of Critical Care and Nephrology, London SE1 9RT, UK

${ }^{2}$ St George's Hospital, Department of Nephrology \& Transplantation, London SW17 0QT, UK

Corresponding author: Marlies Ostermann, Marlies.Ostermann@gstt.nhs.uk

Published: 31 October 2008

This article is online at http://ccforum.com/content/12/5/432

(c) 2008 BioMed Central Ltd

Patients with advanced acute kidney injury (AKI) and endstage dialysis dependent renal failure (ESRF) are characterized by loss of renal function as well as significant associated co-morbidities. However, prognosis appears to differ when they are admitted to the intensive care unit (ICU). Patients with advanced AKI have a reported ICU mortality between $25 \%$ and $90 \%$, depending on the specific patient population and the definition of AKI [1,2], whereas ICU mortality in ESRF patients has been reported to be $9 \%$ to 26\% [3-5]. In contrast, Uchino and coworkers [5] found no difference in outcome between 32 ESRF patients in an ICU
Critical Care 2008, 12:432 (doi:10.1186/cc7085)

and 32 diagnosis and severity score matched patients with AKI treated with renal replacement therapy (RRT).

We retrospectively analyzed the Riyadh Intensive Care Program database of 41,972 adult patients admitted to ICUs in 19 hospitals in the UK and three hospitals in Germany between 1989 to 1999, and we compared ESRF patients and patients with advanced AKI (defined by serum creatinine $\geq 354 \mu \mathrm{mol} / \mathrm{l}$, treatment with RRT or a rise in serum creatinine by $>300 \%$ from baseline). A total of 797 patients had preexisting ESRF and 2,782 patients had advanced $\mathrm{AKI}$, of

Table 1

\section{Characteristics of patients with AKI and ESRF}

\begin{tabular}{|c|c|c|c|c|}
\hline Factor & $\begin{array}{l}\text { Advanced AKI } \\
\text { without RRT } \\
(n=935)\end{array}$ & $\begin{array}{l}\text { AKI on RRT } \\
(n=1,847) \\
\end{array}$ & $\begin{array}{c}\text { ESRF } \\
(n=797)\end{array}$ & $\begin{array}{c}P(\mathrm{AKI} \text { on } \mathrm{RRT} \\
\text { versus } \mathrm{ESRF})\end{array}$ \\
\hline Male sex & $67.2 \%$ & $70.6 \%$ & $59.6 \%$ & 0.0002 \\
\hline Mean age $\pm S D$ (years) & $60.1 \pm 15.7$ & $63.1 \pm 15.4$ & $55.3 \pm 16.4$ & 0.062 \\
\hline SOFA score on admission to ICU (median [range]) & 7 (0 to 17$)$ & 10 (1 to 22$)$ & $8(1$ to 8$)$ & 0.11 \\
\hline Organ failure on admission to ICU $(n$; median [range]) & $1(0$ to 4$)$ & $2(0$ to 6$)$ & 0 (0 to 4$)$ & $<0.0001$ \\
\hline Nonsurgical admission & $65.2 \%$ & $69 \%$ & $54.8 \%$ & $<0.0001$ \\
\hline Emergency surgery & $17.1 \%$ & $13.2 \%$ & $13.9 \%$ & 0.64 \\
\hline Maximum organ failures in ICUa ( $n$; median [range]) & $1(0$ to 6$)$ & $2(0$ to 6$)$ & $0(0$ to 5$)$ & $<0.0001$ \\
\hline Mechanical ventilation & $78 \%$ & $91.3 \%$ & $60.9 \%$ & $<0.0001$ \\
\hline Haemoglobin $\leq 9 \mathrm{~g} / \mathrm{dl}$ on admission to ICU & $20.6 \%$ & $26.9 \%$ & $42.7 \%$ & $<0.0001$ \\
\hline Cardiac surgery & $10.2 \%$ & $12.8 \%$ & $11.4 \%$ & 0.935 \\
\hline ICU mortality & $40.6 \%$ & $54.1 \%$ & $20.8 \%$ & $<0.0001$ \\
\hline Hospital mortality & $50.5 \%$ & $61.6 \%$ & $34.5 \%$ & $<0.0001$ \\
\hline Length of stay in ICU (days; median [range]) & 7 (1 to 270$)$ & 10 (1 to 219$)$ & $2(1$ to 64$)$ & $<0.0001$ \\
\hline
\end{tabular}

aExcluding renal failure. AKI, acute kidney injury; ESRF, end-stage renal failure; ICU, intensive care unit; OR = odds ratio; RRT, renal replacement therapy; SD, standard deviation; SOFA, Sequential Organ Failure Assessment. 
(a) Incidence $[\%]$

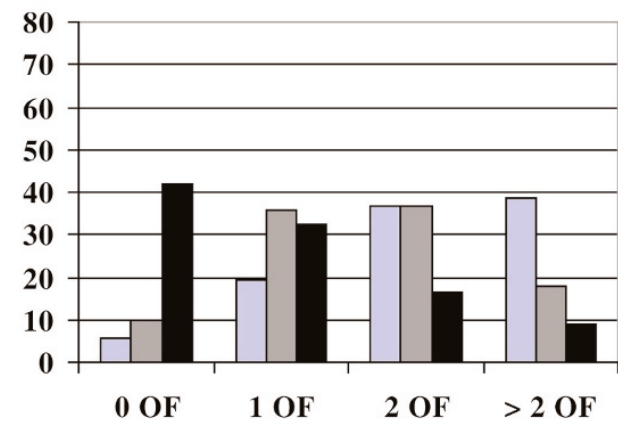

(b) ICU mortality [\%]

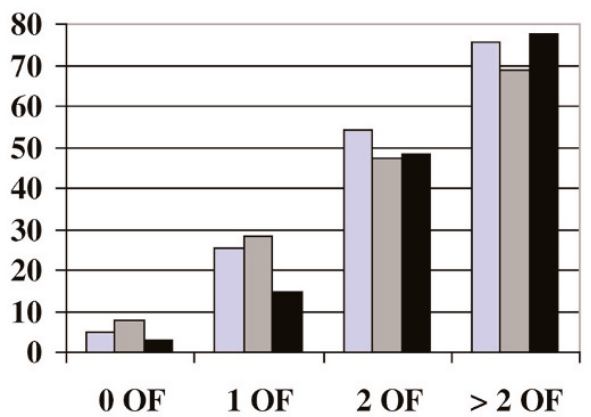

Associated maximum organ failure and impact on outcome. Shown are (a) incidence (\%) and (b) ICU mortality (\%). AKI, acute kidney injury; ESRF, end-stage renal failure; ICU, intensive care unit; OF, maximum associated organ failure during stay in ICU (excluding renal failure); RRT, renal replacement therapy.

whom $66.4 \%$ were treated with RRT. ESRF patients had a significantly lower ICU and hospital mortality and shorter stay in ICU compared with patients with advanced AKI (Table 1). In both groups the ICU mortality rate rose with increasing number of associated failed organ systems (Figure 1). However, patients with AKI had significantly more associated organ failures during their stay in the ICU; $75.4 \%$ of patients with AKI on RRT and $54.5 \%$ of patients with advanced AKI not on RRT had two or more other failed organ systems, in contrast to only $25.6 \%$ of ESRF patients. In addition, significantly more patients with AKI on RRT needed mechanical ventilation compared with ESRF patients (91.3\% versus $60.9 \%, P<0.0001)$.

In a multivariate analysis, mechanical ventilation (odds ratio $(O R)=3.3$, maximum number of failed organs (OR $=2.93$ ) and nonsurgical admission ( $O R=2.1$ ) were the strongest independent risk factors for ICU mortality, followed by emergency surgery $(\mathrm{OR}=1.75)$, pre-existing chronic disease $(\mathrm{OR}=1.2)$, SOFA score on admission to ICU (OR =1.05) and age $(\mathrm{OR}=1.03)$.

Our study confirms that patients with ESRF admitted to ICU had a significantly better prognosis than did ICU patients with advanced AKI. The main reasons were due to differences in co-morbid risk factors, in particular need for mechanical ventilation and associated organ failure while in the ICU.

\section{Competing interests}

The authors declare that they have no competing interests.

\section{Authors' contributions}

Mr R Chang is in charge of the Riyadh Intensive Care Program database. Both authors extracted the data from the database and performed the analyses. Dr Ostermann wrote the draft and Mr Chang provided critiques. Both authors approved the final manuscript.

\section{Acknowledgements}

We wish to thank the Riyadh ICU Program Users Group for access to the data used in this study.

\section{References}

1. Mehta RL, Pascual MT, Soroko S, Savage BR, Himmelfarb J, Ikizler A, Paganini EP, Chertow GM, for the Program of Improve Care in Acute Renal Disease: Spectrum of acute renal failure in the intensive care unit: the PICARD experience. Kidney Int 2004, 66:1613-1621

2. Uchino S, Kellum JA, Bellomo R, Doig GS, Morimatsu H, Morgera S, Schetz M, Tan I, Bouman C, Macedo E, Gibney N, Tolwani A, Ronco C, for the Beginning and Ending Supportive Therapy for the Kidney (BEST Kidney) Investigators: Acute renal failure in critically ill patients: a multinational, multicenter study. JAMA 2005, 294:813-818.

3. Hutchison CA, Crowe AV, Stevens PE, Harrison DA, Lipkin GW: Case mix, outcome and activity for patients admitted to intensive care units requiring chronic renal dialysis: a secondary analysis of the ICNARC Case Mix Programme Database. Crit Care 2007, 11:R50.

4. Dara SI, Afessa B, Bajwa AA, Albright RC: Outcome of patients with end-stage renal disease admitted to the intensive care unit. Mayo Clin Proc 2004, 79:1385-1390.

5. Uchino S, Morimatsu H, Bellomo R, Silvester W, Cole L: Endstage renal failure patients requiring renal replacement therapy in the intensive care unit: incidence, clinical features, and outcome. Blood Purif 2003, 21:170-175. 